UDC 811.111'373:78

DOI https://doi.org/10.32841/2409-1154.2020.46-2.8

\author{
Muradkhanian I. S., \\ Candidate of Philological Sciences, \\ Associate Professor at the Department of Foreign Languages for the Humanities \\ Yuriy Fedkovych Chernivtsi National University
}

Hladkoskok L. H.,

Candidate of Philological Sciences,

Associate Professor at the Department of Foreign Languages for the Humanities

Yuriy Fedkovych Chernivtsi National University

Semen H. Ya.,

Candidate of Philological Sciences,

Associate Professor at the Department of Foreign Languages for the Humanities

Yuriy Fedkovych Chernivtsi National University

\title{
MODERN MUSIC PROFESSIONALLY LIMITED VOCABULARY IN THE SYSTEM OF THE ENGLISH LANGUAGE
}

\begin{abstract}
Summary. The absence of clear criteria for distinguishing between different layers of professionally limited vocabulary in the system of the language is an explanation of so many differences in the treatment of terms, professionalisms, jargonisms and slang. The suggested working definitions of these groups of special vocabulary is an attempt to overcome this difficulty. It is necessary to pay more attention to the criteria for stylistic differentiation of professionally limited vocabulary. The present research is based on I. R. Halperin's concept and understanding of regarding professionally limited vocabulary. Having defined the groups of special music vocabulary the analysis of 50 units was undertaken with the result of its constituting 4,16\% of all 1200 words in I. Ayto's "The Longman Register of New Words", 1987. According to the types of formation single words, compounding derivation prevail, words are more in number than word combinations. As to the parts of speech, the majority of words are nouns, formal words prevail over informal. Among the units there can be found borrowings from other languages: Latin and Hindi; French and Italian suffixes can be traced. Words from other sphere enter the music vocabulary and vice versa. Regional variants are represented by Americanisms. Some words become outdated due to the innovative technologies and rapid technological progress. Contextual analysis proved that only some words have positive implication, but mostly they are used with negative one. In the informative style the analysed words are used with the aim of informing the readers and listeners about the news in music world. Some stylistic devices can be found in the context created with the help of music words: morphologic repetition, antithesis, metaphor, from the syntactical point of view one-member exclamatory sentence with music word can be found. The perspective of research is the investigation of music professionally limited vocabulary in belleslettres and colloquial functional styles.
\end{abstract}

Key words: music, term, professionalism, jargonism, slang, word formation types, context.

General outline of the problem and its links with the important scientific and practical issues. Terms, professionalisms and jargon are three traditionally distinguished layers of profession- ally limited vocabulary in linguistics. Still, the question of their differentiation can not be considered definitely resolved, it is difficult to draw out a clear demarcation line between them.

In modern English lexicography there is often a "substitution of concepts" when, for example, jargon is interpreted through the concept of a term. In particular, in dictionaries of modern music vocabulary [17].

This phenomenon can be explained by the absence of clear criteria for distinguishing between terminological and slang vocabulary. It is evidenced by the very definition of jargon. In English language dictionaries [19]. jargon is defined as follows:" technical terminology unique to a particular subject; technical terminology or characteristic idiom of a special activity or group; terminology used in a certain profession, such as computer jargon".

Based on these interpretations, it is difficult to distinguish what a word really is - a term or professionalism (or, for example, jargon0, because in both cases, we are talking about the designation of some object (phenomenon, process) characteristic of a certain profession or type of activity. This is associated with difficulties in isolating terms from many authentic sources, especially modern on-line music dictionaries.

Let's refer to examples of jazz Glossary of terms [18].

Blow - the usual term for "improvise". Also, simply to play an instrument.

Legit - the jazz musician's somewhat ironic term for music, or a gig, that is not jazz.

Outro - a jocular term for coda; an added ending section.

Here the dictionary definition of the lexeme "blow" contains the word "term". This, however, cannot be considered a sufficient reason for classifying the unit as a term, since its definition contains a synonym "to improvise", while the defined word is a metonymy, and a synonym "to improvise" is a primary nomination.

The definitions of "legit" and "outro" units along with the reference word "term" contain its emotional characteristics (ironic, jocular), which can be considered as an implicit confirmation of the substandard stylistic status and it doesn't allow to classify the indicated units actually as terms. 
Analysis of the latest investigations and publications on the given theme, emphasizing the previously unsolved parts of the general problem the article is devoted to.

The same lexical units in other dictionaries are defined as jazz musicians slang (jazz slang). On the other hand, the virtual slang dictionary uses "term" instead of "slang". For example: Blow A jazzman's term for playing any instrument (e.g. That European guy, Django Reinhardt can easily "blow") [16]. Along with that, the underlined unit is marked "slang, jazz slang" in dictionaries of American slang "Juba To Jive" [10] and "NTC's Dictionary of American Slang And Colloquial Expressions" [14].

The well known researcher in the field of jazz music art, G. L. Dillard defines the stylistic status of such lexical units more vaguely. In the book "Lexicon of Black English" he argues as follows: "Many of the terms discussed below have by now been absorbed by General American English, becoming merely the music-listening public's terms rather than the Black musician's terms for certain music devices, procedures, and experiences" [9, p. 61]. The word "term" here acquires the definition "public" to emphasize the elimination of ethnostylistic specific features (beyond "black" musicians' parlance). The author doesn't comment on the fact, that emotional and expressive character of units in question, and the presence of neutral synonyms doesn't allow to consider them strictly terms, c.f. licorice stick (clarinet), slush pump (trombone) etc. [9, p. 69].

The author of the dictionary "Rockspeak! The Dictionary of Rock Terms" Tom Hibbert doesn't draw a demarcation line between terms and reduced vocabulary, classifying quite different groups of words as rock music terms: "music business and record company jargon, musical genre and dance craze definitions, fan terminology, music press clichés etc" [10, p. 5].

Rick McRae in the article "What Is Hip? And Other Inquires in Jazz Slang Lexicography" trying to distinguish between "jazz terms" and "jazz argot", refers such units, as "bark", "yelp", "meow", "horse-neigh", "laugh", "sneeze" to the number of terms [12, p. 3]. The author tries to justify his point of view by the fact that "The New Grove Dictionary of Jazz" contains 95 terms, which originally could be found in jazz slang dictionaries, and afterwards they acquired a terminological status ("lick", "riff", "bend", "shout" etc.) [12, p. 7].

Stylistic amelioration and transition of such units into the sphere of terminological vocabulary is fixed in many lexicographic sources, including the jazz dictionary already mentioned:

bend - "sound effect, pitch bend, played on the guitar, keyboard and wind instruments";

lay back - "deliberately play notes with a slight delay after the beat";

lay out - "stop playing either for a few measures, or for a longer section of a song, or for a whole set";

inside - "to improvise within the harmonic structure of the composition";

outside - "move away in improvisation from the given harmonic structure of the composition

ride out - "perform the last chorus of a fast composition, jointly improvising in a loud, enthusiastic manner";

riff - "a short melodic ostinato (ostinato - "a melodic, harmonic or rhythmic turn repeated in a row"), which serves as the basis for improvisation";

shake - "a sound effect reminiscent of a trill or prolonged vibrato, produced on a wind instrument by shaking it while playing"; shout - "a kind of chorus, which is performed by a big band, where the brass section is leading, and is characterized by loudness and inspiration";

sit in - "to play in an ensemble without being a member of it (for example, to replace temporarily one of the musicians)";

smear - "extended band down a semitone or tone and then sharply up again, creating the effect of "dirty" sounding";

stretch out - "to improvise on a given topic for a long period, using as many appropriate techniques and effects as possible";

vamp - "a short, rhythmically and harmonically uncomplicated passage, performed before the introduction of the soloist; the technique of performing is ostinato before or between solo parts, as well as for expansion during or after a solo".

However, none of the special dictionaries analyzed found the terminological use of such units as "bark", "yelp", "meow", "horse-neigh", "laugh", "sneeze" which allows to disagree with Rick McRae and classify these words as jargon vocabulary. At the same time, the word "lick" is defined as jargon: "lick" - in jazz argot a short motif or formula inserted into an improvisation when the context permits or when invention lapses" [13, p. 708].

Thus, determining the words of interest and their status, in the majority of foreign sources there is an undifferentiated use of the words "term" and "slang" (professional/jazz slang) which indicates the absence of strict criteria for stylistic differentiation of professionally limited vocabulary. The problem is most clearly reflected in the title of Karl Kons' article for "The Down Beat" magazine (1935) "The Slanguage of Swing: Terms the Cats Use", where "cats"(slang for jazz musicians) appears along with the words "terms" and "slang/slanguage". It's worth noting, that in English-language sources, which we have already addressed to, professionalisms as a special layer of vocabulary, are not singled out at all.

The situation is somewhat different in the works of Russian authors, however, here as well it is difficult to draw out clear boundaries between these layers of professional vocabulary. A lot of researchers don't clearly differentiate them, commenting only on the basic properties of terminological vocabulary [Shelov 1984; Grinev 1993; Podkolzina 1992; Samorukova 2001].

One of the most detailed is I. R. Halperin's concept [1, p. 76-77]. Based on his definitions the following features of terms distinguish them from other layers of professional vocabulary:

- conventional character;

- naming a new concept of science

- direct relation to the terminological system of corresponding branch of science, art;

- predominant use in special literature;

The definition of "jargon" is given as follows: "jargon is a reorganized term for a group of words that exists in almost every language and its aim is to preserve secrecy within one or another group". At the same time, two differences of terms from jargon and professionalisms are indicated:

1) the use of terms in literary and book vocabulary;

2) terms are created to define newly emerging concepts as a result of scientific discoveries and technological progress, while professionalisms and jargon denote in a new way already known concepts [1, p. 109, 113].

A number of investigations is dedicated to structural and semantic analysis of music terminology [5], [4], jargon [2], modern English slang [3], [6]. They include valuable observa- 
tions, vivid examples, thorough analysis of special vocabulary of the language.

Traditionally music terminology is subdivided into verbal and graphic [5, p. 123]. In musical terminology of performance English music terms are not so active [5, p. 124]. The authors emphasize the relativity of the boundaries that isolate different types of special types of special vocabulary groups [6, p. 86]. Compiling of dictionaries, glossaries, preparing reference-books and chapters of textbooks devoted to music which are used in the teaching process, explaining of lexical units and word combinations to music majors, text interpretation is hard to achieve without systematic monitoring and investigating of the processes that take place in the vocabulary of music world. I. V. Arnold argues that "the study of changes occurring in a group of terms or a whole terminological subsystem can give very valuable data" [7, p. 213].

The aim of the article is to differentiate and define the special vocabulary of music, analyze ways of their formation and their functioning in the text. Thus, the following tasks become the priority: 1) to find and single out the examples of music words in different sources; 2) to differentiate and define them illustrating with examples; 3) to analyze ways of their word-formation by means of calculations and presentation by means of the table; 4) to show their functioning in the context.

Presentation of the main material of investigation with thorough grounding of the obtained scientific results.

First and foremost it is necessary to define words of special music vocabulary.

Music term is a word or word-combination used to name a notion characteristic of music field including instruments, performance, notation etc. Examples may be: note, keyboard, quartette, tuning fork, baton, pianist, rhapsody, rock, soloist, solfeggio, soprano, suite, chord, flat, octave, C (do), measure / US meter et al. They are semantically narrow terms. Music terminology as a system reflects the notions belonging to the sphere of music.

Professionalisms are the words used in the sphere of music profession as calling by people of common interests both at work and at home but are not terms. They name anew already-existing concepts, instruments, trends in music. According to I. R. Galperin, the main feature of a professionalism is its technicality and its link to a common occupation and interests [1, p. 113]. Professionalisms are dimmed by the image on which they are based, at the same time they are very helpful for they make quicker and easier the performance of the musicians. E.g. axe / ax: a musical instrument, esp. a jazz musician's guitar, trumpet or saxophone; ivories: piano keys; super: Music Supervision; bag: short of "bag of tricks" or also used as a catch all for what a player is into; head: the melody of a tune, often played through as bookends to the solos; comp: short for "accompany" - to support a soloist; diamond: a whole note; "Two Down / Two up": "Up" meaning sharps, "Down" meaning flats, sometimes just shown with a handsign; call: to suggest a song for playing.

According to L. P. Yefimov and E. A Yasinetskaya [15] jargonisms are non-standard words used by people of a certain social group to keep their intercourse secret. The authors cite the explanation of Eric Partridge, an authority on the subject, for the creation and use of jargon: the desire to be different, startling, or original, to display belonging to a group, a fraternity which is closed for outsiders, to enrich the vocabulary of the language, make friends easily, being irreverent or humorous [15, p. 27-28]. Music jargon can be illustrated by the following examples: spellken = a play house or theatre, lark = fun or sport of any kind (used by J. J. Byron [1, p. 110]), jargonisms found in modern sources: nutty = pleasing; fan = admirer (dejargonised); ear candy: pleasant-sounding music, earworm: a song that repeats annoyingly in one's head; in-thepocket: the music is good; trap set/skins: drums, a monster: a great jazz musician; noodlin: not paying attention and playing aimlessly. Guitar players are notorious noodlers; wood-shed: to practice or place to practice.

The authors of Modern Slang Dictionary John Ayto and John Simpson define slang as a highly colloquial or informal vocabulary below the level of standard educated speech, and consisting either of new words or current words employed in some new special sense. The vocabulary of slang changes rapidly [8]. Examples of it in the sphere of music may be: blastissimo; rock'n'roll slang for extremely high volume, seat surfing; moving from one unoccupied seat to another at a concert; a bullet: a song or album that's rising rapidly in "the charts", honk: to improvise; lizard: a bad note.

In the dictionary entitled "The Longman Register of New words" [8] John Ayto built up a rounded picture of the ways in which English had grown, emphasizing that "by definition, the introduction of new words - and of new meanings for old ones - reflects developments and innovations in the world at large and in society" [8]. It can occur within the limits of certain social groups and professional sphere of activity. The author indicates the verbal turnover in the realm of music alongside other spheres. All in all the dictionary contains more than 1200 lexical units. Over 130 sources were used in compiling the collection. Melody and New Music Express being among them. The Longman Citation Bank provided the basis for the book. Out of all the words music lexical units constitute 50 units $-4,16 \%$. According to the types of word formation one can cite (Table 1).

J. Ayto correctly indicated that the frontiers of language advance more precipitously in vocabulary than in any other area, at the same time words of pop scene are putting in appearances of unpredictable duration [8]. The researcher considers blending to be the most productive (rockumentaries: rock + documentary). In the sphere of music, as can be seen from the table above, predominant are words (38) over word combinations (12), where two elements words (11) greatly prevail over three elements formations (1). The leading ways of creating new words in music are single words, compounding, derivation, old words with new meaning. Blending, clipping, conversion and acronymy as both main (conversion) and secondary ways of word formation are very modestly manifested. One cannot find in this selection any reduplication or sound imitation. As to the parts of speech these lexical units are mostly nouns (46) with 3 verbs and 1 adjective respectfully. The majority of words is formal (36) and a group less in number belongs to informal vocabulary (10) and slang (4). Examples of slang are: muso noun, derogatory slang a pop musician who is pedantically concerned with technical minutiae; cut noun, slang a single song of other item on an LP (long playing record); a track; diss verb slang to reject or dismiss contemptuously; put down. It is apparently an abbreviation of disrespect, originally in Black American Rap culture. This lexical unit having appeared in the sphere of music became widely used. Though, J. Ayto considers -bo to be an arbitrary suffix in the word grebo noun, British slang (a member of) a youth cult, Harlytska T. S. argues that suffix $\underline{-0}$ that has no special meaning renders the word a special slangish colouring [2]. 


\begin{tabular}{|c|c|c|c|}
\hline \multicolumn{2}{|c|}{ Types of word formation } & Number & Example \\
\hline \multicolumn{2}{|c|}{ Single word } & 8 & hook noun, informal a repeated, typically catchy melodic phrase in a popular music composition \\
\hline \multicolumn{2}{|l|}{ compounding } & 8 & speed-metal noun a style of powerfully amplified rock music with a very fast heavy beat \\
\hline \multicolumn{2}{|l|}{ derivation } & 6 & mixer noun a disc jockey skilled in presenting music from a pair of turntables \\
\hline \multicolumn{2}{|c|}{ Acronym(abbreviation) } & 2 & MOR adjective, informal (in pop music) middle of the road; stylistically unadventurous \\
\hline \multirow{2}{*}{ clipping } & the beginning & 1 & $\begin{array}{l}\text { house noun, a style of pop music featuring electronically simulated or modified effects and intended chiefly for } \\
\text { dancing to. From Warehouse, a club in Chicago }\end{array}$ \\
\hline & the end of the word & 2 & $\begin{array}{l}\text { goth noun (a pop musician favoring) a serious, rather austere style of rock music - from gothic noun an adherent } \\
\text { of the goth music cult }\end{array}$ \\
\hline \multicolumn{2}{|l|}{ conversion } & 2 & jazzercise noun exercising to a musical accompaniment of jazz \\
\hline \multicolumn{2}{|c|}{ blending } & 4 & agitpop noun the use of pop music to put across a political message (agitation+popular) \\
\hline \multicolumn{2}{|c|}{ old word new meaning } & 5 & pogo verb to jump up and down on the spot to music from pogo stick whose movements it imitates \\
\hline \multirow{2}{*}{$\begin{array}{l}\text { Word } \\
\text { combination }\end{array}$} & 2 elements & 11 & thrash metal - a style of rock music \\
\hline & 3 elements & 1 & compact video disc noun (abbreviation CDV) a compact laser disc which plays both pictures and sound \\
\hline \multicolumn{2}{|l|}{ All in all } & 50 & \\
\hline
\end{tabular}

The gre-element presumably derives from greaser, a long-haired member of a motorcycle gang.

Some words are used in transferred meaning, metaphor bring the basis of coinage: chicken-dancing noun a type of dancing to pop music. When a new notion (device, equipment, object) appears in people's activity it usually acquires a new name.

But with time new innovative technologies make it secondary, even a bit outdated. E.g. CDV, CD, CDS - these discs are changed in their usage and substituted be other kinds of discs suitable for computers of new generation and notebooks. Some words originated in other spheres and came to be used in the music scene. E.g. crossfader noun a device used by discjockeys to transfer smoothly from one record to another. This originated in the language of backstage technology, where it refers to fading out of one set of lights and the simultaneous bringing up of another. There is also a reverse direction, when a word being first used in the music would became a common word for the people who even do not suspect of its music origin. Thus, the concept of the masterclass started in the world of music and is now used in a whole range of disciplines. From the point of view of their origin, there can be found alongside purely English words, some units from other languages. There is a word with distinct Latin origin: dectet noun a group of ten singers or instrumentalists and one word borrowed from Hindi: Bhangra noun a variety of pop music originated in the Indian community in Britain, based on Punjabi folk music but with various elements of Western rock incorporated into it.

Among the selected words there are units formed by means of suffixes common in Italian: jazzerati noun plural celebrated or distinguished jazz musicians, and French: bimbette noun American informal an adolescent female pop singer. A coinage is based on the voguish word bimbo which had been around for a long time especially in American English. It is Italian in origin, meaning a "little child". One can also find American words and meanings: beach music noun a style of American pop music based on black soul music and rhythm and blues and originating on the coast of South Carolina. It had its associated dance, the SHAG and is known internationally.

One of the key issues in analyzing music words in their functioning in the context. In the music journals and newspapers music critics give definitions, systematically presenting new groups, bands, trends to the public. Thus, the main function becomes that of informing the readers of the upcoming music events. But they also show their own attitude to which is not necessarily favourable which can be seen from the following example of irony: Anthrax are a trash metal band named after a sheep disease; with all respect to the sheep, the disease is almost certainly preferable to the band. Daily Telegraph 4 May 1987. The effect is obviously humorous. Some words like agitpop give positive implication. The unit comes from agitpop (agitation + propaganda), the use of literature, music, alt, etc for propaganda purposes. But negative implication prevails in the context: acid house, aristopop, muso, sampling pomp rock, diss. Music word becomes more expressive when used in one-member exclamatory sentence: "Grebo! The dirty denims!" New Musical Express 23 July 1987. The word Bhangra is used to create metaphor: "and suddenly Bhangra fever too over". News on Sunday 11 Monday 1987. Another example provides the adjective deaf before the noun in plural musos which enhances negative evaluation of some pop musicians' performance. The noun goth is used to form lexical antithesis with the help of contextual antonyms. Goth has a tendency to darkness which is reflected in its strict all-black dress code: "We've gone from complete goth to total bright pop". Melody Marker 10 January 1987. Morphologic repetition is used to show "an uninhibited physical mania": trashing, dive-bombing, writhing ('moshing'), dirty-tackling.

Conclusions and perspectives of further research in the given direction. The issue of differentiation of terms, professionalisms, jargon and slang as layers of professionally limited vocabulary in linguistics is of great importance. Substitution or combining the notions at random should be avoided. With this aim the working definitions for these linguistic phenomena were suggested in the present article. To illustrate the definitions words and word combinations from different sources were used. Modern music professionally limited vocabulary proves to be very rich and diverse reflecting the new notions that came into being in the recent time. The constant and assiduous attention to the described linguistic phenomena gives the possibility to track and define new trends and creations in the world of music. In future it would be preferable to concentrate more on the functioning of music professionally limited vocabulary not only in the realm of informative style, but belleslettres style as well. The sphere of colloquial style can also provide the researchers with new and unexpected findings. 


\section{References:}

1. Гальперин, И.Р. Стилистика английского языка / И.Р. Гальперин. Учебник. Изд. 2-е, испр. и доп. Москва : Высшая школа, 1977. $332 \mathrm{c}$.

2. Гарлицька Т.С. Словотвірний потенціал жаргонної лексики (на матеріалі української, російської та англійської мов). Вісник КНЛУ. Серія Філологія. 2015, № 2, т. 18. С. 23-29.

3. Глущак Н. Лінгвопрагматика сучасного англомовного сленгу : витоки, класифікаційні та семантичні ознаки. Вісник Львівського університету. Серія іноземної мови. 2013. Вип. 21. С. 22-36.

4. Павлова О.І. Музична термінологія англійської, французької, російської та української мов у сфері фіксації. Культура народов Причерноморья: научный журнал. 2009. № 168, т. 2. С. 150-153.

5. Степанова О. Структурно-семантичний аналіз музичної термінології виконавського мистецтва. Філологічні науки. Мовознавство. Науковий вісник Східноєвропейського наиіонального університету ім. Л. Украӥнки. 2013. № 1. С. 122-126.

6. Шелов С.Д. Терминология, профессиональная лексика и профессионализмы (К проблеме классификации специальной лексики). Вопросы языкознания. 1984. № 5. С. 76-87.

7. Arnold I. V. The English Word, 1973. 303 p.

8. Ayto J. The Longman Register of New Words. Special Edition. London : Longman Group. UK Ltd, 1989. 434 p.

9. Dillard, J. Lexicon of Black English. N.Y., 1977. 199 p.

10. Hibbert Tom. The Dictionary of Rock Terms. L., N.Y., Sydney : Omnibus Press, 1983. 176 p.

11. Juba to jive: the dictionary of African American slang. Major, Clarence. N.Y.: Penguin Books, 1994. 592 p.

12. McRae, R. 'What is hip?' and other inquiries in jazz slang lexicography/ R. McRae. Music Library Association, Inc. 2001. Vol. 57. Issue 3. P. 574.

13. New Grove dictionary of jazz. 2nd ed. New York : Grove, 2002.

14. "NTC's Dictionary of American Slang And Colloquial Expressions (2000). Spears, Richard A.; NTC Publishing Group. Lincolnwood (Chicago), Ill. : NTC Pub. Group - 2000.

15. Yefimov L. P., Yasinetskaya E. A. Practical Stylistics of English. Vinnytsia : Nova Knyha, 2004. 240 p.

16. All about Jazz. 2021. URL : http://www.allaboutjazz.com.

17. Dictionary of jazz slang, Dictionary of hip hop slang. URL : https:// www.the-jazz-cat.com/jazz-slang-dictionary.html.

18. Glossary of Jazz Terms. An arbitrary list of common jazz terms from the perspective of the jazz piano student. URL : http://www.sonic. net/ jazz4/glossary.html.
19. The American Heritage Dictionary 2000; The Columbia Electronic Encyclopedia 2003. URL : https://www.ahdictionary.com/.

Мурадханян І. С., Гладкоскок Л. Г., Семен Г. Я. Сучасна спеціальна лексика музики у системі англійської мови

Анотація. Відсутністю точних критеріїв для виділення різноманітних пластів професійної спеціальної лексики у системі мови пояснюється велика кількість відмінностей у трактуванні термінів, професіоналізмів, жаргонізмів та сленгу в науковій літературі. Запропоновані робочі визначення даних груп спеціальної лексики $є$ спробою подолати такі труднощі. Необхідно приділяти більшу увагу критеріям стилістичної диференціації професійної спеціальної лексики у сфері музики. Дане дослідження базується на концепції I. Р. Гальперіна та його розумінні спеціальних лексичних груп. Після визначення спеціальної лексики у сфері музики було здійснено аналіз 50 одиниць з результатом 4,16\% із 1200 одиниць у словнику нових слів Дж. Ейто, 1987. За типом словотвору окремі слова, складені слова, деривація переважають. Окремі слова за чисельністю більші, ніж словосполучення. Щодо частин мови, то переважна більшість припадає на іменники, знижена лексика менша, ніж міжстильова. Серед лексичних одиниць знаходимо запозичення з інших мов: латинської та хінді, наявні також французькі та італійські суфікси. Лексичні одиниці із інших сфер переходять до сфери музики та навпаки. Регіональні варіанти представлені американізмами. Деякі слова стають застарілими через новітні технології та швидкий технологічний прогрес. Контекстуальний аналіз показав, що лише деякі слова мають позитивне забарвлення, а більшість із них вживаються із негативною імплікацією. У інформативному стилі проаналізовані лексичні одиниці використовуються з метою сповістити читачам та слухачам про новини у світі музики. Деякі стилістичні засоби, зафіксовані у контексті, створені за допомогою лексичних одиниць сфери музики: морфологічний повтор, антитеза, метафора, з синтаксичної точки зору зустрічається вигукове одночленне речення. Преспективою дослідження $є$ вивчення спеціальної лексики музичної сфери у художньому та розмовному функціональних стилях.

Ключові слова: музика, термін, професіоналізм, жаргонізм, сленг, типи словотвору, контекст. 